\title{
Anti-inflammatory Constituents from the Roots of Saposhnikovia divaricata
}

\author{
Young-Won Chin, Yoo Hyun Jung, ${ }^{\dagger}$ Hee-Sung Chae, ${ }^{\dagger}$ Kee Dong Yoon, ${ }^{\S}$ and Jinwoong Kim ${ }^{\dagger, *}$ \\ College of Pharmacy, Dongguk University-Seoul, Seoul 100-715, Korea \\ ${ }^{\dagger}$ College of Pharmacy and Research Institute of Pharmaceutical Science, Seoul National University, Seoul 151-742, Korea \\ *E-mail: jwkim@snu.ac.kr \\ ${ }^{*}$ Bio-Therapeutics Research Institute, Korea Research Institute of Bioscience and Biotechnology, Cheongwongun, \\ ChungBuk 363-883, Korea \\ ${ }^{\S}$ College of Pharmacy, Catholic University, Bucheon, Gyeonggi-do 420-743, Korea \\ Received March 24, 2011, Accepted May 2, 2011
}

Key Words : Saposhnikovia divaricata, Anti-inflammatory, Coumarin, Chromone, Phenyl propanoid fatty acid ester

Saposhnikovia divaricata Schischk. belongs to the family Umbelliferae and grows in the eastern Siberia and northern Asia. ${ }^{1}$ The roots of $S$. divaricata have been used for the treatment of rheumatism, headache, convulsion and nerve paralysis in China and Korea. ${ }^{1}$ Previous study for this plant led to the identification of chemical constituents such as chromones, coumarins, lignans, polyacetylenes, and sterols, ${ }^{2}$ as well as biological activities including analgesic, ${ }^{3}$ antiproliferative, ${ }^{4}$ antioxidant, ${ }^{4}$ and iNOS inhibitory activities. ${ }^{5}$ As a part of our search for anti-inflammatory constituents of plant origin, ${ }^{6,7}$ this plant was selected for further follow-up isolation work. In the present study, we described the isolation and structures elucidation of a new compound and 13 known compounds (Fig. 1), and the evaluation of their<smiles>CCCCCCCCCCCCCCCCCCCCCC(=O)OCC(O)C(OC)(OC)c1ccc(O)c(OC)c1</smiles><smiles>[R]c1cc(=O)c2c(O)c3c(cc2o1)OC(C)(C)C([R20])C3</smiles>

$\mathrm{R}_{1}$

$\mathrm{R}_{2}$<smiles>C/C=C(/CC(=O)OCCO)C(C)=O</smiles><smiles>CC(O)C(C)(O)C(=O)OC(C)(C)C1Cc2cc3ccc(=O)oc3cc2O1</smiles>

13<smiles>CC1(C)Oc2cc3oc(CO)cc(=O)c3c(O)c2CC1O</smiles>

6<smiles>CC(C)(O)[C@H]1Cc2cc3ccc(=O)oc3cc2O1</smiles>

8<smiles>COc1cc2ccc(=O)oc2c(OC)c1O</smiles>

10<smiles></smiles>

11<smiles>COc1c2c(cc3oc(C)cc(=O)c13)O[C@H](C(C)(C)O)C2</smiles>

7<smiles>C/C=C(/C)C(=O)OC1c2c(ccc3ccc(=O)oc23)OC(C)(C)[C@H]1OC(=O)/C(C)=C\C</smiles><smiles></smiles>

Figure 1. Structures of Compounds 1-14. 


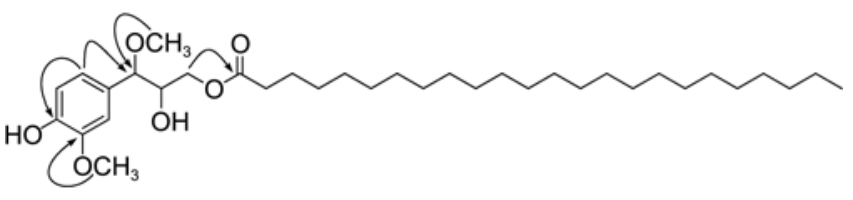

Figure 2. Key HMBC correlations of compound 1.

inhibitory activity on nitric oxide production in LPS-induced mouse macrophages RAW264.7.

Compound 1 was isolated as an amorphous powder, and its molecular formula was deduced as $\mathrm{C}_{35} \mathrm{H}_{62} \mathrm{O}_{6}$ from a sodiated molecular ion peak at $m / z 601.4448[\mathrm{M}+\mathrm{Na}]^{+}$ (Calcd for $\mathrm{C}_{35} \mathrm{H}_{62} \mathrm{O}_{6} \mathrm{Na}$, 601.4444) in the HRFABMS. The ${ }^{1} \mathrm{H}$ NMR spectrum of $\mathbf{1}$ displayed a 1,3,4-trisubstituted benzene unit resonating at $\delta_{\mathrm{H}} 7.23(1 \mathrm{H}, \mathrm{d}, J=8.0 \mathrm{~Hz}, \mathrm{H}-5)$, $7.22(1 \mathrm{H}, \mathrm{d}, J=1.7 \mathrm{~Hz}, \mathrm{H}-2)$, and $7.08(1 \mathrm{H}, \mathrm{dd}, J=8.0,1.7$ $\mathrm{Hz}, \mathrm{H}-6)$, two oxymethines at $\delta_{\mathrm{H}} 4.47(1 \mathrm{H}, \mathrm{m}, \mathrm{H}-7)$ and 4.43 $(1 \mathrm{H}, \mathrm{m}, \mathrm{H}-8)$, an oxymethylene at $\delta_{\mathrm{H}} 4.52(1 \mathrm{H}, \mathrm{dd}, J=10.7$, $3.0 \mathrm{~Hz}, \mathrm{H}-9)$ and 4.37, (1H, dd, $J=10.7,6.0 \mathrm{~Hz}, \mathrm{H}-9)$, a fatty acid moiety at $\delta_{\mathrm{H}} 2.37\left(2 \mathrm{H}, \mathrm{t}, J=7.5 \mathrm{~Hz}, \mathrm{H}-2{ }^{\prime}\right), 1.64$ $\left(2 \mathrm{H}, \mathrm{q}, J=7.4 \mathrm{~Hz}, \mathrm{H}-3^{\prime}\right), 1.22-1.28\left(-\mathrm{CH}_{2} \mathrm{n}-\right)$, and $0.84(3 \mathrm{H}$, $\left.\mathrm{t}, J=6.8 \mathrm{~Hz}, \mathrm{H}-16^{\prime}\right)$, along with two methoxy groups at $\delta_{\mathrm{H}}$ $3.72\left(-\mathrm{OCH}_{3}\right)$ and $3.58\left(-\mathrm{OCH}_{3}\right)$, suggestive of the presence of a phenylpropanoid fatty acid ester. The connectivities between phenylpropanoid and fatty acid, and the position of two methoxy groups were established by HMBC correlations (Fig. 2). The long range correlations of both $\delta_{\mathrm{H}} 4.52$ and $4.37(\mathrm{H}-9)$ to $\delta_{\mathrm{C}} 173.6\left(\mathrm{C}-1^{\prime}\right)$ confirmed the location of fatty acid on C-9 through an ester linkage. The three-bond correlations of both $\delta_{\mathrm{H}} 3.58\left(\mathrm{OCH}_{3}\right)$ and $7.08(\mathrm{H}-6)$ to $\delta_{\mathrm{C}}$ 85.8 enabled to affix a methoxy group to $\mathrm{C}-7$. The remaining methoxy group was placed on $\mathrm{C}-3$ by the observation of HMBC correlations between $\delta_{\mathrm{H}} 3.72$ and $\delta_{\mathrm{C}} 148.7$ (C-3) as well as $\delta_{\mathrm{H}} 7.08(\mathrm{H}-6)$ and $\delta_{\mathrm{C}} 148.8(\mathrm{C}-4)$. Thus, this compound was identified as a phenylpropanoid fatty acid ester. Furthermore, in order to determine the absolute configuration of C8 , Mosher derivatives $(R \mathbf{- 1}$ and $S \mathbf{- 1})$ of compound $\mathbf{1}$ were prepared but it was found that this compound is present in a racemic mixture since ${ }^{1} \mathrm{H}-\mathrm{NMR}$ data of $R-1$ exhibited two distinctive peaks at $\delta_{\mathrm{H}} 5.58$ and 5.53 with a ratio of $c a 1: 1$ based on the integral of H-8. This inference was further supported by the value of specific rotation, $\left([\alpha]_{\mathrm{D}}^{24} 0\right)$. Therefore, this compound was determined to be $( \pm)$-2-hydroxy-3(4-hydroxy-3-methoxyphenyl)-3-methoxypropyl nervonic acid ester, isolated from natural sources for the first time.

The known compounds were confirmed as hamaduol (2), ledebouriellol (3), ${ }^{2}$ divaricatol (4), ${ }^{2}$ 3-O-acetylhamaudol (5), ${ }^{2}$ melanochrome (6), ${ }^{2}$ 5-O-methylvisamminol (7), ${ }^{2}$ marmesin (8), ${ }^{2}$ anomalin (9), ${ }^{2}$ isofraxidin $(\mathbf{1 0})^{3}$, fraxidin (11) ${ }^{8}$ methoxy-8-(3-hydroxymethyl-but-2-enyloxy)-psoralen (12), ${ }^{9}$ lindiol (13), ${ }^{10}$ and byakangelicin $(\mathbf{1 4})^{11}$ by the interpretation and comparison of their spectroscopic data $\left({ }^{1} \mathrm{H},{ }^{13} \mathrm{C}, 2 \mathrm{D}\right.$ NMR, MS, and $[\alpha]_{D}$ ) and the published values. Of the known compounds, compounds 12-14 were isolated from this plant for the first time.

All the isolates were evaluated for their inhibitory activity on nitric oxide production in LPS-induced mouse macro- phages RAW264.7 and it was found that divaricatol (4), and methoxy-8-(3-hydroxymethyl-but-2-enyloxy)-psoralen (12) were moderately active constituents with $\mathrm{IC}_{50}$ values of 39.2 and $36.4 \mu \mathrm{g} / \mathrm{mL}$ without cytotoxicity (cell viability $>90 \%$, data not shown).

\section{Experimental Section}

General Procedures. Optical rotation was measured with a JASCO DIP-1000 digital polarimeter (Tokyo, Japan). FABMS spectra were obtained on a JEOL JMS-AX505WA. UV and IR spectra were recorded on a Shimadzu UV-2101 and JASCO FT/IR-300E, respectively. ${ }^{1} \mathrm{H}-\mathrm{NMR}$ and ${ }^{13} \mathrm{C}-\mathrm{NMR}$ spectra were recorded on a Bruker spectrometer at $500 \mathrm{MHz}$ and at $125 \mathrm{MHz}$, respectively. Column chromatography was performed using a Sephadex LH-20 (Pharmacia) and Kiesegel 60 (Art. 7734; Merck, Darmstadt, Germany). RPMPLC was carried using a ISCO Combiflash (Lincoln, NE, USA) instrument with a UV/vis detector (UA-6). A Gilson HPLC system (Middleton, WI, USA) was used to isolate compounds, and was equipped with two 321 pumps, a UV/ vis-151 detector, an autosampler 234 and a fraction collector 204. A column of YMC (J'sphere ODS-H80, S-4 $\mu \mathrm{m}, 250 \times$ $10 \mathrm{~mm}$ i.d., Japan) was used for isolation of compounds. TLC was conducted on pre-coated Kiesegel $60 \mathrm{~F}_{254}$ plates (Art. 5715; Merck, Darmstadt, Germany). Spots on the TLC were detected under UV light.

Plant Materials. The roots of $S$. divaricata were collected in Mongolia in February 2007, and were identified by Prof. Je-Hyun Lee, College of Oriental Medicine, Dongguk University. A voucher specimen (SNUPH-0629) has been deposited in the Medicinal Herb Garden, Seoul National University.

Extraction and Isolation. The air-dried and chopped roots of $S$. divaricata $(10 \mathrm{~kg})$ were extracted with methanol three times using ultrasonication for $90 \mathrm{~min}$ each. The methanol extract $(1.4 \mathrm{~kg})$ was partitioned with EtOAc and $n$ $\mathrm{BuOH}$ sequentially. A portion of the EtOAc-soluble fraction (565 g) was subjected to a silica gel column chromatography (230-400 mesh) using gradient elution of $n$-hexane-EtOAc system (100:0-0:100) to afford 11 fractions (F01-F11). Fraction F01 was subjected to a silica gel column chromatography ( $n$-hexane-EtOAc=100:0-0:100) and gave nine subfractions (F0101-F0109). From F0101, compound 5 (3 mg) was separated by the repeated silica gel column chromatography, eluting with a mixture of $n$-hexane and EtOAc, and $\mathrm{CHCl}_{3}$ and $\mathrm{MeOH}$, respectively. $\mathrm{F} 0103$ was fractionated by sequentially a silica gel (a mixture of $\mathrm{CHCl}_{3}$ and $\mathrm{MeOH}$ ) and Sephadex $(\mathrm{MeOH})$ columns, and yielded compound 9 (34 mg). Subfraction F0105 was applied to a MPLC with a gradient solvent of $n$-hexane and EtOAc (9:1-1:1) and pooled into seven subtractions (F010501-F010507). HPLC separation for F010501, using YMC column eluted with a gradient of water and $\mathrm{MeOH}(50: 50-30: 70,2 \mathrm{~mL} / \mathrm{min})$ led to the isolation of compounds $2\left(t_{\mathrm{R}} 7.9 \mathrm{~min}, 6.1 \mathrm{mg}\right)$ and $11\left(t_{\mathrm{R}}\right.$ $5.9 \mathrm{~min}, 3.3 \mathrm{mg}$ ). HPLC purification for a portion of F010502 using aforementioned method afforded compounds $4\left(t_{\mathrm{R}}\right.$ 
$29.0 \mathrm{~min}, 9.8 \mathrm{mg})$, and $\mathbf{1 2}\left(t_{\mathrm{R}} 20.8 \mathrm{~min}, 4.0 \mathrm{mg}\right)$, and the remaining of F010502 was purified by HPLC separation eluting with a gradient of water and $\mathrm{MeOH}(40: 60-00: 100,2$ $\mathrm{mL} / \mathrm{min})$ to give compound $3\left(t_{\mathrm{R}} 28.1 \mathrm{~min}, 2.2 \mathrm{mg}\right)$. Using a gradient of water and $\mathrm{MeOH}(45: 55-35: 65,2 \mathrm{~mL} / \mathrm{min})$ in HPLC system equipped with a YMC column, compound 7 ( $t_{\mathrm{R}} 10.2 \mathrm{~min}, 6.7 \mathrm{mg}$ ) was separated from F010505. HPLC purification for $\mathrm{F} 010507$ using a gradient of water and $\mathrm{MeOH}$ (45:55-25:75, $2 \mathrm{~mL}$ ) provided compound $6\left(t_{\mathrm{R}} 10.1 \mathrm{~min}, 4.5\right.$ $\mathrm{mg}$ ). Combined fractions H30 (F0107 to F0109) was loaded on a MPLC, eluted with gradient mixtures of $\mathrm{CHCl}_{3}$ and $\mathrm{MeOH}$ (100:0-95:5) to give two fractions (H301 and H302). From H301, compounds $8\left(t_{\mathrm{R}} 51.7 \mathrm{~min}, 1.5 \mathrm{mg}\right)$ and $\mathbf{1 0}\left(t_{\mathrm{R}}\right.$ $10.8 \mathrm{~min}, 2.7 \mathrm{mg}$ ) were purified using HPLC separation with a gradient solvent of water and $\mathrm{MeOH}(65: 35-35: 65,2 \mathrm{~mL} /$ $\mathrm{min}$ ). From H302, compounds $\mathbf{1 3}\left(t_{\mathrm{R}} 26.0 \mathrm{~min}, 5.3 \mathrm{mg}\right.$ ) and $14\left(t_{\mathrm{R}} 28.3 \mathrm{~min}, 4.7 \mathrm{mg}\right)$ were isolated by HPLC separation (water and $\mathrm{MeOH}=60: 40-35: 65,2 \mathrm{~mL} / \mathrm{min}$ ). Fractions F08 was rechromatographed on a silica gel [230-400 mesh, hexaneEtOAc (20:1-0:1)], and gave 10 subfractions (F0801-F0810). Subfraction F0806 was further chromatographed on a silica gel using a gradient of $n$-hexane-EtOAc (10:1-0:1) and furnished compound $\mathbf{1}(12 \mathrm{mg})$ from F080605.

2-hydroxy-3-(4-hydroxy-3-methoxyphenyl)-3-methoxypropyl nervonic acid ester (1): amorphous powder; $[\alpha]_{\mathrm{D}}^{24} 0(c 0.05$, $\mathrm{MeOH}$ ); IR (neat) $v_{\max } 3438,2918,1727,1631,1524,1468$, $1170 \mathrm{~cm}^{-1}$; HRFABMS (positive ion mode): $m / z 601.4448$ $[\mathrm{M}+\mathrm{Na}]^{+}$(Calcd for $\left.\mathrm{C}_{35} \mathrm{H}_{62} \mathrm{O}_{6} \mathrm{Na}, 601.4444\right)$; ${ }^{1} \mathrm{H}-\mathrm{NMR}$ (pyridine- $\left.d_{5}, 500 \mathrm{MHz}\right) \delta 7.23(1 \mathrm{H}, \mathrm{d}, J=8.0 \mathrm{~Hz}, \mathrm{H}-5), 7.22$ $(1 \mathrm{H}, \mathrm{d}, J=1.7 \mathrm{~Hz}, \mathrm{H}-2), 7.08$ (1H, dd, $J=8.0,1.7 \mathrm{~Hz}, \mathrm{H}-6)$, $4.52(1 \mathrm{H}, \mathrm{dd}, J=10.7,3.0 \mathrm{~Hz}, \mathrm{H}-9), 4.47(1 \mathrm{H}, \mathrm{m}, \mathrm{H}-7), 4.43$ (1H, m, H-8), 4.37 (1H, dd, $J=10.7,6.0 \mathrm{~Hz}, \mathrm{H}-9), 3.72$ $\left(-\mathrm{OCH}_{3}, \mathrm{C}-3\right), 3.58\left(-\mathrm{OCH}_{3}, \mathrm{C}-6\right), 2.37(2 \mathrm{H}, \mathrm{t}, J=7.5 \mathrm{~Hz}, \mathrm{H}-$ 2), $1.64(2 \mathrm{H}, \mathrm{q}, J=7.4 \mathrm{~Hz}, \mathrm{H}-3), 1.22-1.28(40 \mathrm{H}, \mathrm{H}-4$ to H23), $0.84\left(3 \mathrm{H}, \mathrm{t}, J=6.8 \mathrm{~Hz}, \mathrm{H}-244^{\prime}\right) ;{ }^{13} \mathrm{C}-\mathrm{NMR}\left(\mathrm{CD}_{3} \mathrm{OD}, 125\right.$ MHz) $\delta 173.6$ (C-1'), 148.8 (C-3), 148.7 (C-4), 130.6 (C-1), 121.3 (C-6), 116.3 (C-2), 111.7 (C-5), 121.6 (C-6), 85.8 (C7), 73.5 (C-8), 66.4 (C-9), 34.4 (C-2'), 32.1* (C-23'), 30.0$29.0\left(-\mathrm{CH}_{2} \mathrm{n}-\right), 25.3\left(\mathrm{C}-3^{\prime}\right), 22.9 *\left(\mathrm{C}-22^{\prime}\right), 14.2\left(\mathrm{C}-24^{\prime}\right) .{ }^{*}$ The assignments are interchangeable.

MTPA Derivatives of Compound 1. Compound 1 (2.3 $\mathrm{mg}$ ) was dissolved in $\mathrm{CH}_{2} \mathrm{Cl}_{2}$ and then MTPA chloride was added. After $48 \mathrm{hr}$ later, reaction mixture was purified by a silica gel chromatography $\left(\mathrm{CHCl}_{3}-\mathrm{MeOH}=100: 0,40: 1\right)$ and furnished $R$-MTPA derivative of $\mathbf{1}(\boldsymbol{R}-\mathbf{1}, 2.7 \mathrm{mg}) . S$ MTPA derivative of $\mathbf{1}(\boldsymbol{S}-\mathbf{1}, 2.3 \mathrm{mg})$ was prepared using aforementioned method. These derivatives deemed to be racemic mixtures based on the integral of $\mathrm{H}-8$ with duplicate signals at $\delta 5.575$ and 5.533 which were observed in both $R$ MTPA and $S$-MTPA derivatives of $\mathbf{1}$.

$R$-MTPA derivative of $\mathbf{1}$ displayed two set of ${ }^{1} \mathrm{H}$-NMR chemical shifts for H-7, H-8 and H-9. First set of ${ }^{1} \mathrm{H}-\mathrm{NMR}$ $\left(\mathrm{CDCl}_{3}, 900 \mathrm{MHz}\right): \delta 5.575(1 \mathrm{H}, \mathrm{m}, \mathrm{H}-8), 4.259(1 \mathrm{H}, \mathrm{d}, J=$ $7.2 \mathrm{~Hz}, \mathrm{H}-7), 4.310(1 \mathrm{H}, \mathrm{dd}, J=14.9,2.7 \mathrm{~Hz}, \mathrm{H}-9 \mathrm{a}), 3.918$ (1H, dd, $J=14.9,9.9 \mathrm{~Hz}, \mathrm{H}-9 \mathrm{~b})$. Second set of ${ }^{1} \mathrm{H}-\mathrm{NMR}$
$\left(\mathrm{CDCl}_{3}, 900 \mathrm{MHz}\right): \delta 5.533(1 \mathrm{H}, \mathrm{m}, \mathrm{H}-8), 4.363(1 \mathrm{H}, \mathrm{d}, J=$ $7.2 \mathrm{~Hz}, \mathrm{H}-7), 4.191$ (1H, dd, $J=15.3,2.7 \mathrm{~Hz}, \mathrm{H}-9 \mathrm{a}), 3.776$ $(1 \mathrm{H}, \mathrm{dd}, J=15.3,7.2 \mathrm{~Hz}, \mathrm{H}-9 \mathrm{~b})$. The assignments were completed based on ${ }^{1} \mathrm{H}-{ }^{1} \mathrm{H}$ COSY correlation. ${ }^{1} \mathrm{H}-\mathrm{NMR}$ data of $S$-MTPA derivative were almost identical to those of $R$ MTPA derivative.

MTT Assay for Cell Viability. The cell viability was examined by MTT assay. ${ }^{7}$ RAW264.7 cells were seeded at $5 \times$ $10^{4} / \mathrm{mL}$ densities in 96 well plates (Nunc, Denmark). Each group had non-treated group as control. Test compounds $(50 \mu \mathrm{g} / \mathrm{mL})$ were added to each well and incubated for $24 \mathrm{~h}$ at $37^{\circ} \mathrm{C}, 5 \% \mathrm{CO}_{2}$. 3-(4,5-dimethylthiazol-2-yl)-2,5-diphenylthiazolium bromide (MTT) solutions $(5 \mathrm{mg} / \mathrm{mL})$ were added to each well and then cells were cultured for another $4 \mathrm{~h}$. The supernatant was discarded and $100 \mu \mathrm{L}$ of dimethyl sulfoxide (DMSO) was added to each well. The optical density was read at $590 \mathrm{~nm}$. Cytotoxicity was calculated by subtracting from one the ratio of the mean absorbance value for treated cells over the mean absorbance value for untreated cells.

Measurement of Nitric Oxide (NO) Production. NO production was assayed by measuring nitrite in supernatants of cultured RAW264.7 cells. ${ }^{7}$ Cells were seeded at $5 \times 10^{5} \%$ $\mathrm{mL}$ in 96 well culture plates. After pre-incubation of RAW264.7 cells for 18 hours, cells were pretreated with test compounds $(50 \mu \mathrm{g} / \mathrm{mL})$ and stimulated LPS $(1 \mu \mathrm{g} / \mathrm{mL})$ for $24 \mathrm{~h}$. The supernatant was mixed with an equal volume of Griess reagent ( $1 \%$ sulfanilamide, $0.1 \%$ naphthylethylenediamine dihydrochloride, and $2.5 \%$ phosphoric acid) and incubated at room temperature for $5 \mathrm{~min}$. The concentration of nitrite was measured by reading at $570 \mathrm{~nm}$. Sodium nitrite $\left(\mathrm{NaNO}_{2}\right)$ was used as a standard curve.

Acknowledgments. This work was supported by the Korean Food and Drug Administration (09112 Crude Drugs 890).

\section{References}

1. Bae, K. H. The Medicinal Plants of Korea; Kyo-Hak: Seoul, 2000; p 380.

2. Kim, S. J.; Chin, Y.-W.; Yoon, K. D.; Ryu, M. Y.; Yang, M. H.; Lee, J.-H.; Kim, J. Kor. J. Pharmacog. 2008, 39, 357.

3. Okuyama, E.; Hasegawa, T.; Matsushita, T.; Fujimoto, H.; Ishibashi, M.; Yamazaki, M. Chem. Pharm. Bull. 2001, 49, 154.

4. Tai, J.; Cheung, S. Oncol. Rep. 2007, 18, 227.

5. Wang, C. C.; Chen, L. G.; Yang, L. L. Cancer Lett 1999, 18, 151.

6. Cai, X.-F.; Chin, Y.-W.; Oh, S.-R.; Kwon, O.-K.; Ahn, K.-S.; Lee, H.-K. Bull. Korean Chem. Soc. 2010, 31, 199.

7. Chin, Y.-W.; Chae, H.-S.; Lee, J.; Bach, T. T.; Ahn, K.-S.; Lee, H.K.; Joung, H.; Oh, S.-R. Bull. Korean Chem. Soc. 2010, 31, 2665.

8. Hiorki, T.; Sueo, H.; Sansei, N. Chem. Pharm. Bull. 1985, 33, 4069.

9. Bilkis, H.; Horst, R.; Anita, A.; Otto, S.; Simon, G.; Michael, H. Phytochemistry 2005, 66, 649.

10. Abyshev, A. Z. Khim. Prir. Soedin. 1974, 5, 568.

11. Kazuhisa, I.; Miwako, F.; Takayuki, A.; Yasuharu, M.; Yoko, W.; Toshihiko, Y.; Hideo, K.; Shigeru, O.; Mitsukazu, K. J. Chromatgr. $B$ 2001, 753, 309 . 


\title{
Anti-inflammatory Constituents from the Roots of Saposhnikovia divaricata
}

\author{
Young-Won Chin, Yoo Hyun Jung, ${ }^{\dagger}$ Hee-Sung Chae, ${ }^{\ddagger}$ Kee Dong Yoon, ${ }^{\S}$ and Jinwoong Kim ${ }^{\dagger}, *$
}

College of Pharmacy, Dongguk University-Seoul, Seoul 100-715, Korea

College of Pharmacy and Research Institute of Pharmaceutical Science, Seoul National University, Seoul 151-742, Korea *E-mail: jwkim@snu.ac.kr

*Bo-Therapeutics Research Institute, Korea Research Institute of Bioscience and Biotechnology, Cheongwongun, ChungBuk 363-883, Korea

${ }^{\S}$ College of Pharmacy, Catholic University, Bucheon, Gyeonggi-do 420-743, Korea

Received March 24, 2011, Accepted May 2, 2011 
${ }^{1} \mathrm{H}-\mathrm{NMR}$

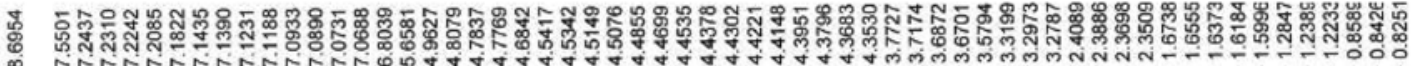

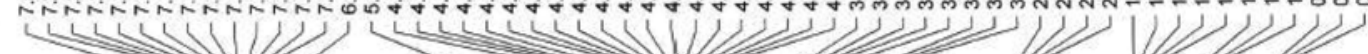

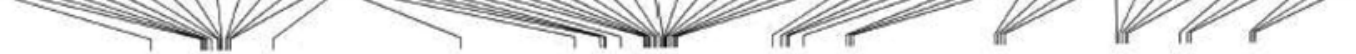

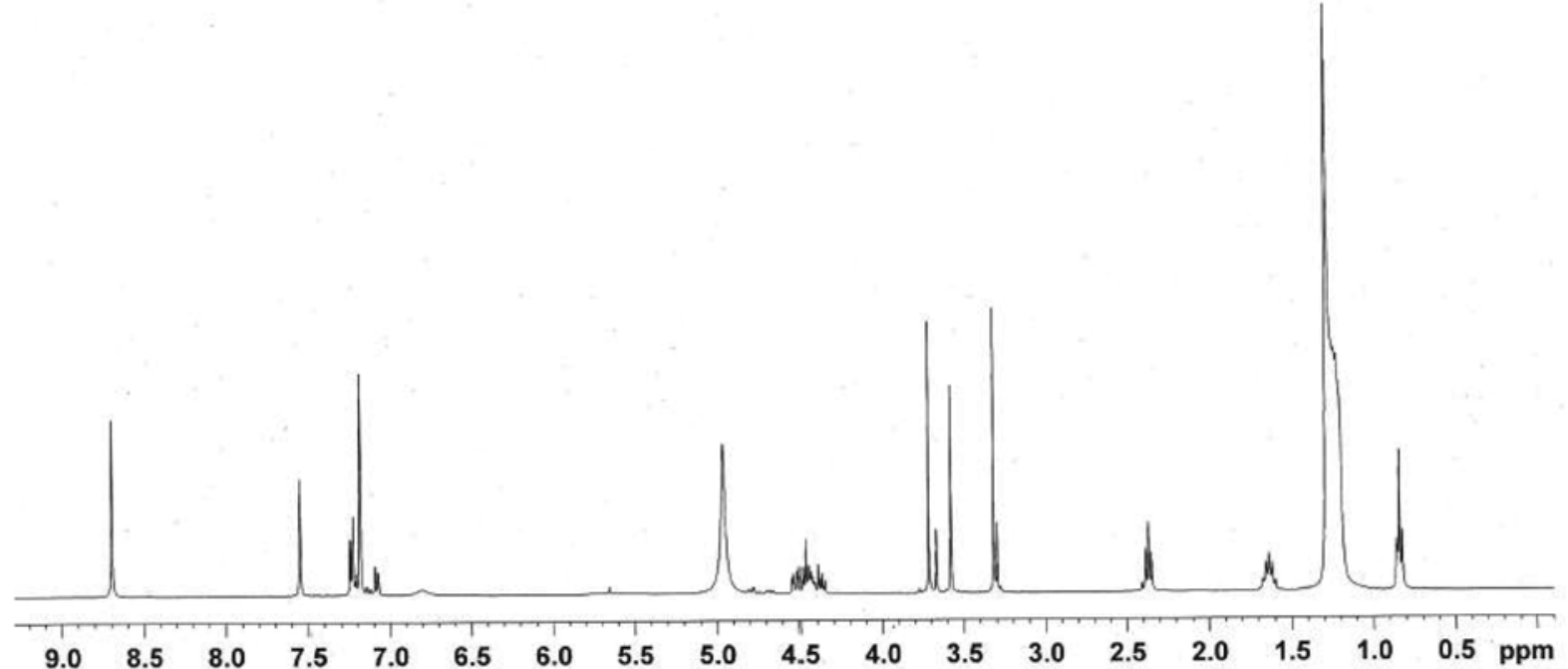

${ }^{13} \mathrm{C}-\mathrm{NMR}$

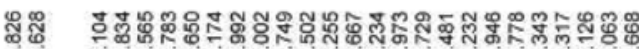

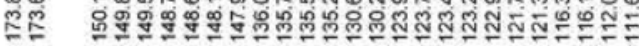

Y

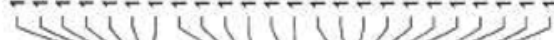

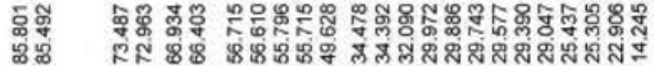

VVWV MW

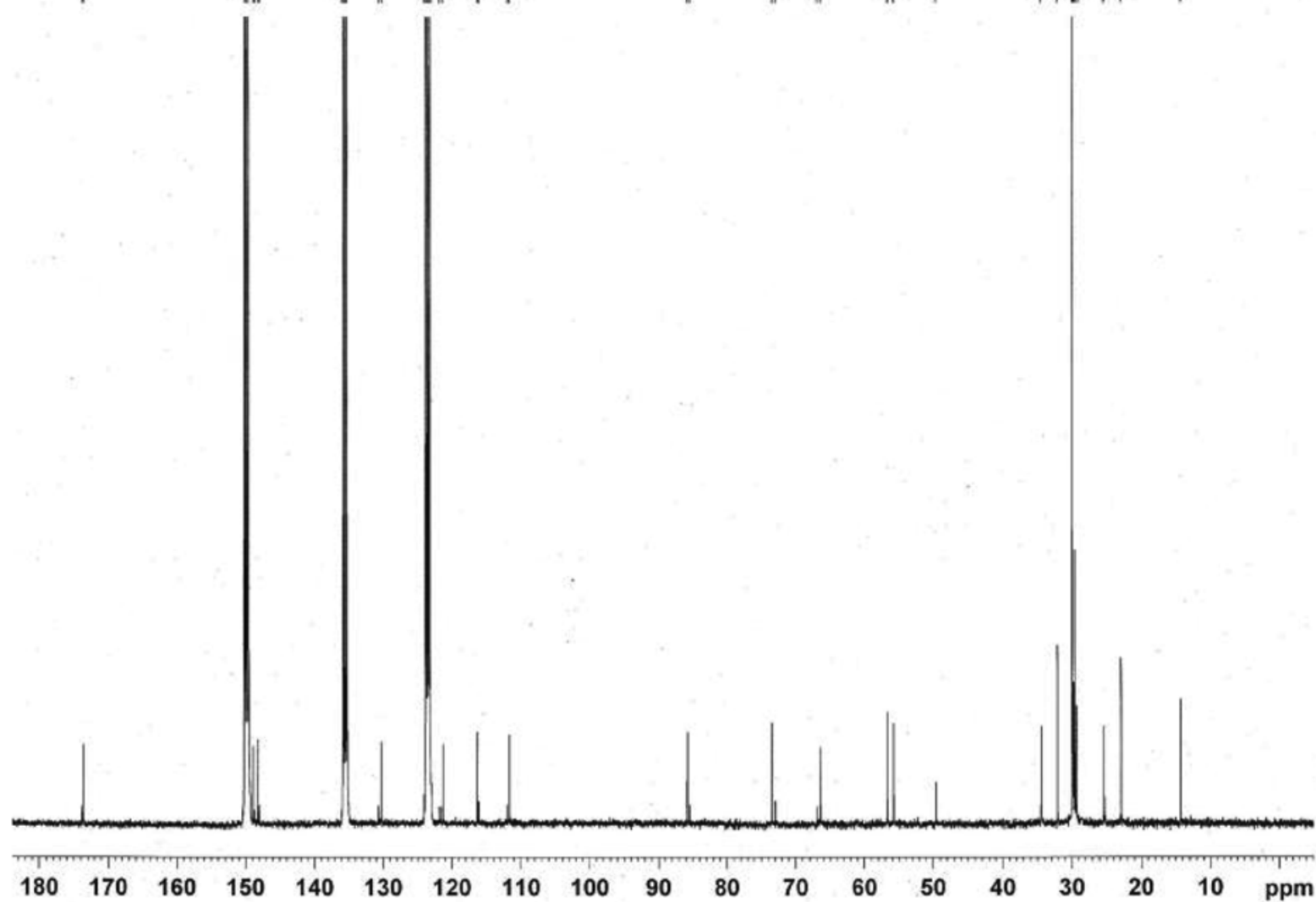




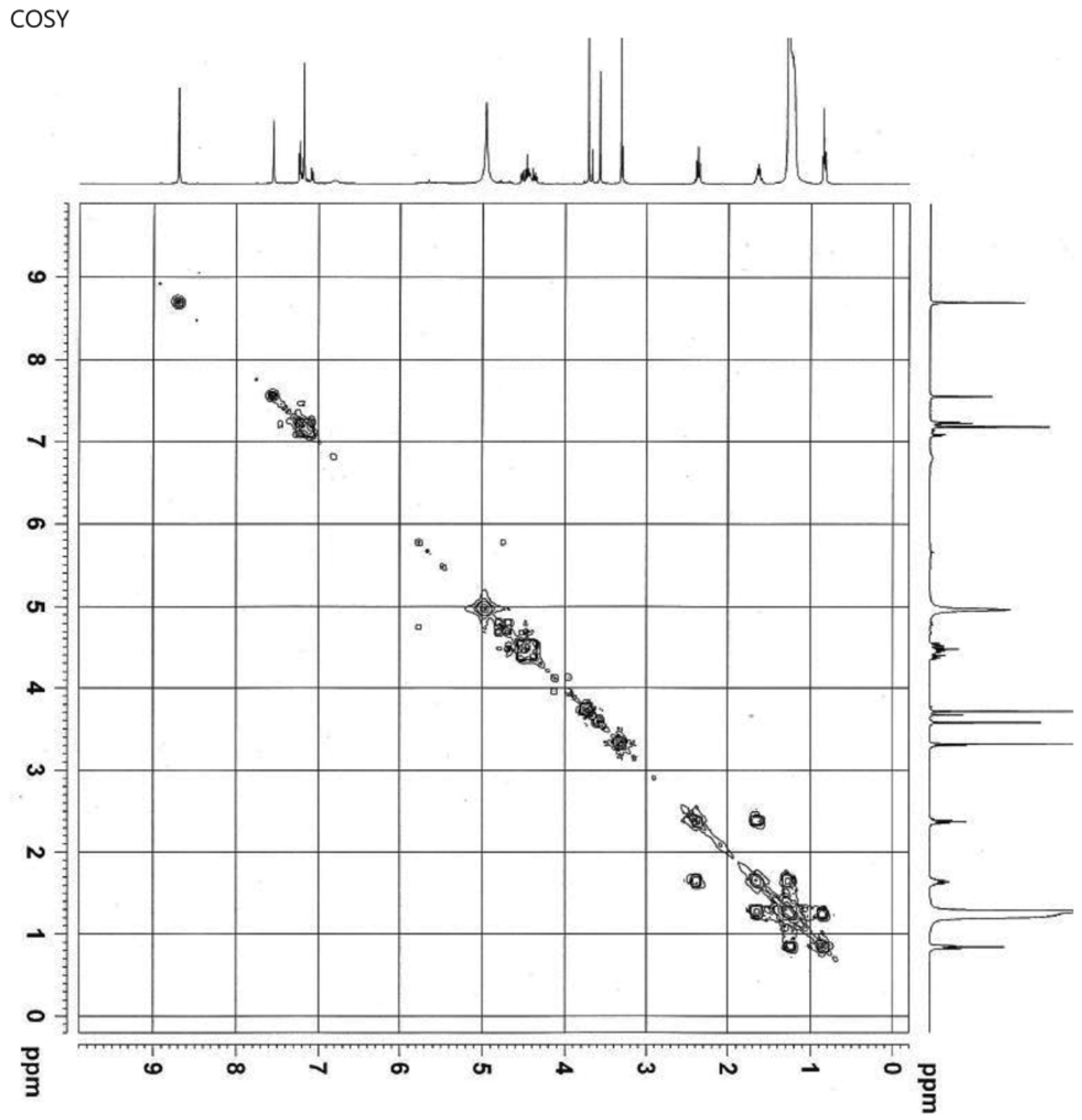


HMQC

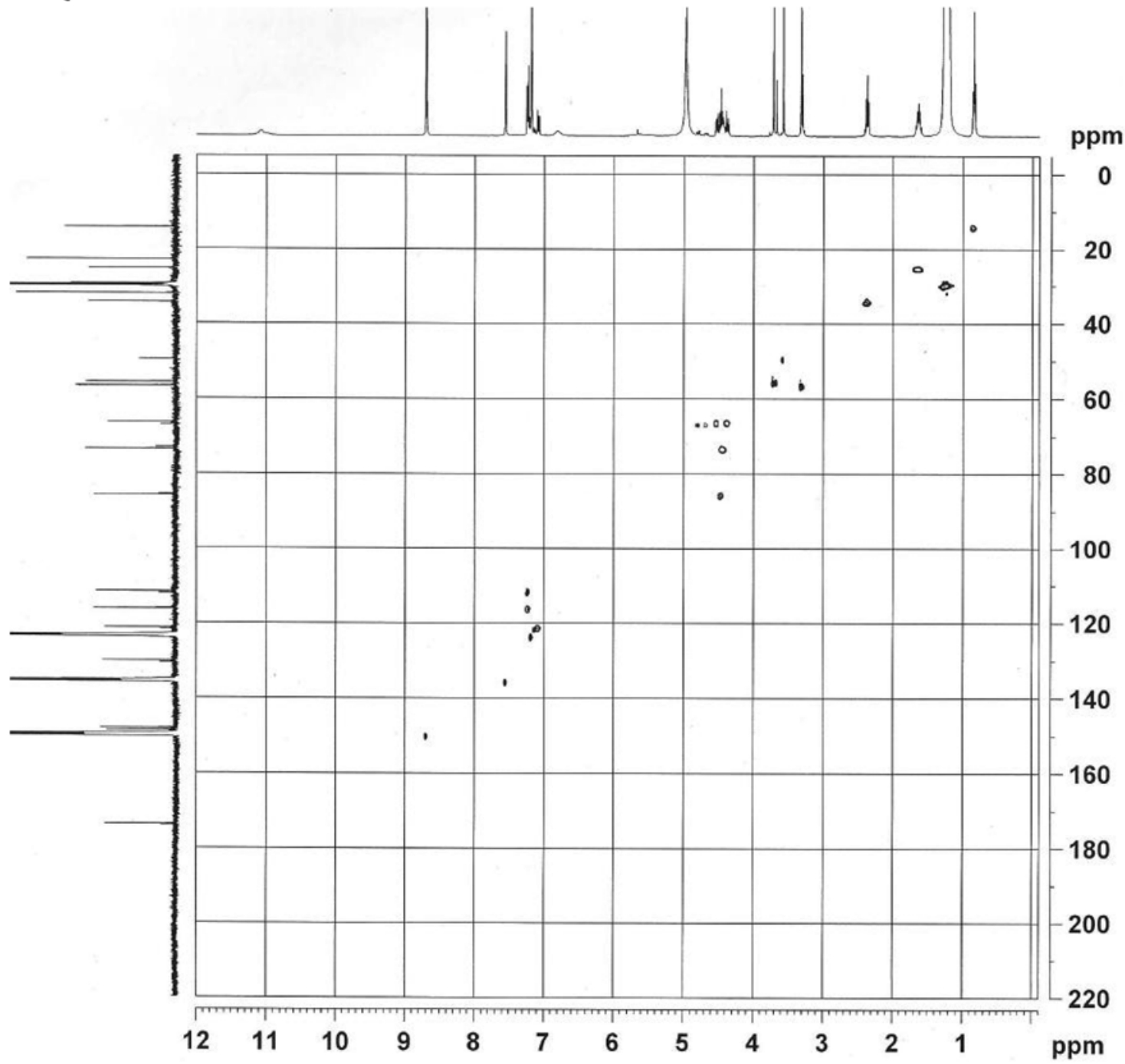


HMBC

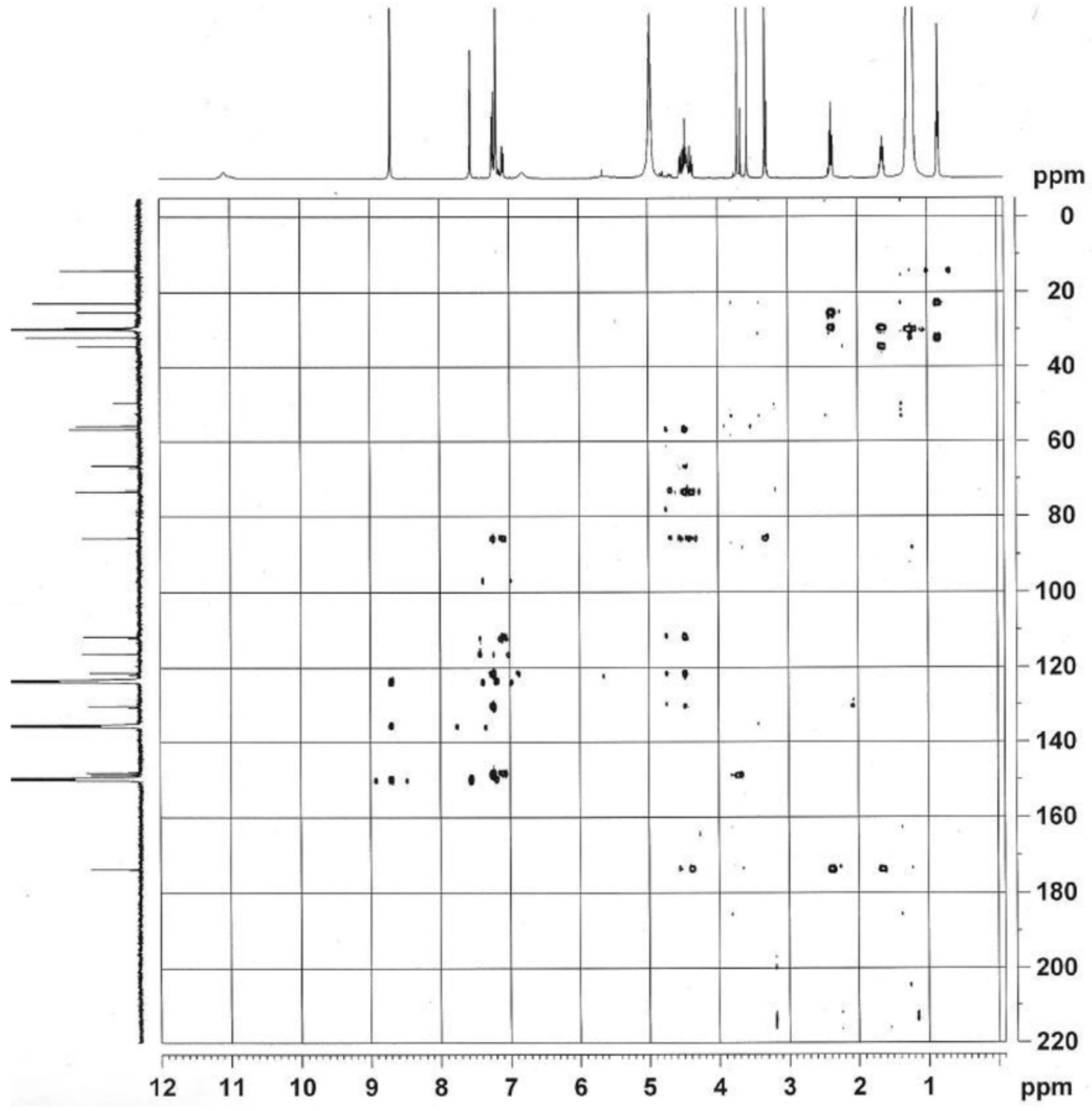

